Original Article

\title{
Phallus eversion sexing in Phrynops geoffroanus (Testudines: Chelidae): a new non-invasive approach
}

\author{
Sexagem por eversão do falo em Phrynops geoffroanus (Testudines: Chelidae): uma \\ nova abordagem não invasiva
}

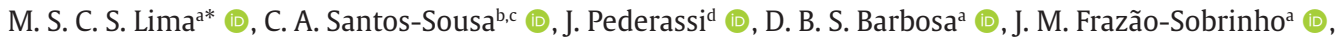

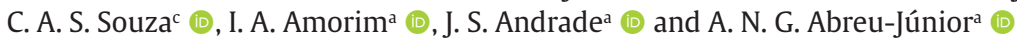 \\ aUniversidade Federal do Piauí - UFPI, Campus Amilcar Ferreira Sobral, Floriano, PI, Brasil \\ 'Universidade Federal do Acre - UFAC, Centro de Ciências Biológicas e da Natureza, Rio Branco, AC, Brasil \\ 'Universidade Federal Rural do Rio de Janeiro - UFRRJ, Seropédica, RJ, Brasil \\ dAssociação Educacional Dom Bosco - AEDB, Resende, RJ, Brasil
}

\begin{abstract}
The sexing of species is an important tool for population management. In tortoises and turtles, sexing is usually done according to secondary characteristics, such as plastron morphology or phallus eversion techniques. In this paper, we present the phallus eversion method and compare its efficiency to other existing techniques. This new method aims at shortening the management time and reducing the physical aftereffects on the animals, fostering the clinical and reproductive management of Geoffroy's side-necked turtle (Phrynops geoffroanus) and related species. A sample of fifty individuals was taken in the central region of Piauí state, Northeastern Brazil. The proposed method consisted of moving the head from its resting position. The methods achieving a success rate higher than $80 \%$ were compared to each other as for the stimulation time required for phallus eversion. The method as here proposed achieved $100 \%$ efficiency in the sex determination of specimens with a linear carapace length between 10 and $34 \mathrm{~cm}$. Also, when compared to the second most efficient method, it substantially reduced the time needed for managing the specimens (91\%), avoiding possible sequelae in the individuals handled.
\end{abstract}

Keywords: tortoises, turtles, sex ratio, phallus exposure, sexual dimorphism.

\begin{abstract}
Resumo
A sexagem das espécies é uma ferramenta importante para o manejo populacional. Em tartarugas, cágados e jabutis, a sexagem geralmente é feita de acordo com características secundárias, como morfologia do plastrão ou técnicas de eversão do falo. Neste artigo, apresentamos o método de eversão do falo e comparamos sua eficiência com outras técnicas existentes. Este novo método visa encurtar o tempo de manejo e reduzir os efeitos colaterais físicos nos animais, promovendo o manejo clínico e reprodutivo do cágado-de-barbicha (Phrynops geoffroanus) e espécies relacionadas. Uma amostra de cinquenta indivíduos foi coletada na região central do estado do Piauí, Nordeste do Brasil. O método proposto consiste em remover a cabeça de sua posição de repouso. Os métodos que obtiveram índice de sucesso superior a $80 \%$ foram comparados entre si quanto ao tempo de estimulação necessário para a eversão do falo. O método aqui proposto alcançou 100\% de eficiência na determinação do sexo de espécimes com comprimento de carapaça linear entre 10 e $34 \mathrm{~cm}$. Além disso, quando comparado ao segundo método mais eficiente, reduziu substancialmente o tempo necessário para o manejo dos espécimes (91\%), evitando possíveis sequelas nos indivíduos manuseados.
\end{abstract}

Palavras-chave: tartaruga, cágado, razão sexual, eversão do falo, dimorfismo sexual.

\section{Introduction}

The sexing of species is a necessary condition to acknowledge the population and its health condition. It allows us to know the sex ratio, and also allows us to propose conservationist measures integrating the technical knowledge generated by wildlife protection agencies to the popular knowledge of communities using turtles as a source of resources (Ferrara et al., 2016; Molina, 1992, 1998; Silveira et al.,
2012; Stein et al., 2015; Terán, 2008). In the case of tortoises and turtles, sexing is based on morphometry (Garbin et al., 2016; Gibbons and Lovich, 1990; Mosimann and Bider, 1960; Solla et al., 2001) mainly when it comes to the aspect of the plastron, and its concavity in males (Molina, 1992).

Sexing in Phrynops tuberosus (Peters, 1870) was performed by pressing the head and hind limbs in way to

*e-mail: slmauro@ufpi.edu.br

Received: March 13, 2021 - Accepted: August 6, 2021 
promote the phallus eversion (Rodrigues et al., 2014) and stressed the importance of studies aimed at the phallus eversion, as it is a reliable and non-invasive technique for the use of population studies in the field, since invasive methods such as finger insertion in the cloaca (RuedaAlmonacid et al., 2007) are not viable in small animals, and the placing of animals in an upright position, stuck in the walls of plastic buckets or rocking the animal in an upright position (Solla et al., 2001) increases the chances of injuries for the animal and the handler.

Phallus eversion requires a good containment of the animal, due to the risk of bites and scratches. The restraint of turtles is based on manual hand pressure over the thoracic limbs (forelimbs), fixation of the animal in supine position and the use of a tarp involving the limbs, thus, preventing scratching (Andrade et al., 2008); or using drugs to relax the muscles (Santos et al., 2011). Another factor that makes sexing difficult is the size of individuals who may not have sexual characteristics, as the young ones do not have well-defined phenotypes in this sense, like the aspects of the plastron and its concavity (Solla et al., 1998).

The goal here is to test a new method to be used in the field that can allow sexing and reduce handling time and physical sequelae to animals, also contributing to the clinical and reproductive management of the chelonian species (Conceição et al., 2009; Oliveira et al., 2015). Thus, we seek to present a method that allows animal sexing, determining the limiting body size for satisfactory results regarding phallus exposure, reducing damage and its immediately release after handling.

\section{Materials and Methods}

\subsection{Focal species}

The species Geoffroy's side-necked turtle [Phrynops geoffroanus (Schweigger, 1812)], belongs to the Chelidae family, which is endemic from the Colombian Amazon down to Northern Argentina. In Brazil, the species occurs throughout the country (Vogt et al., 2019). Regarding size, it can be up to $70 \mathrm{~cm}$ long. The plastron colours mixed in black and white and the plastron entirely grey, with a dark band on each side of the head and two characteristic barbels (Benício and Fonseca, 2014; Freitas and Silva, 2007).

\subsection{Sampling and sample size}

There were 10 field incursions. The sampling of individuals was stopped as soon as we obtained five Phrynops geoffroanus individuals, for each visit $(\mathrm{n}=50)$. In order to avoid stress and damage to the animal, we used a $45 \mathrm{~cm}$ diameter net with a decoy type lure, embedded in sausage. On entering the trap, the specimen was removed. Sampling sites included Riacho do Leite $\left(6^{\circ} 25^{\prime} \mathrm{S}-43^{\circ} 00^{\prime} \mathrm{W}\right)$ and Riacho Meladão ( $6^{\circ} 45^{\prime \prime} \mathrm{S} 43^{\circ} 00^{\prime} \mathrm{W}$ ) in the municipality of Floriano, central region of Piauí state, Brazil.

\subsection{Morphometrics}

We measured the body mass using precision scales of 100 grams. In addition, we also measured the carapace and plastron length and width, with a precision calliper of $0.03 \mathrm{~mm}$. The linear length of the carapace was measured on the vertebral plates between the cervical and cloacal and on the plastron between the rostral and marginal plates of the cloacal region. The width in the ventral and dorsal region was measured side by side (between right and left antimers), with the carapace between the sixth marginal plates and at the plastron in the fissure between the pectoral and abdominal plates (Molina et al., 2012; Silveira et al., 2012).

\subsection{Handling containment}

We used the protocol proposed by Shine et al. (2015), cooling individuals in a 100 liters $(50 \times 80 \mathrm{~cm})$ EPS polystyrene foam box, removing them when the head was slightly relaxed and easy to handle Santos et al. (2011), this aspect always being evaluated by the same researcher. The animals were kept in boxes with a digital thermometer in the cloaca (internal scale $-20^{\circ}$ to $+70^{\circ} \mathrm{C}$, resolution of $0.1^{\circ} \mathrm{C}$ ) (Pessoa et al., 2008). After sexing, the animals were released to their respective collection sites without injuries.

\subsection{Sexual screening of specimens}

All specimens were submitted to the tests proposed in this study, without prior sexual screening.

\subsection{Phallus stimulation}

Method 1 - Place the finger in the cloaca in species with a sufficiently large tail, is a manual examination of the cloaca that can be done by inserting a lubricated finger inside it and palpating to locate the phallus in the midline along the ventral wall of the cloaca (Rueda-Almonacid et al., 2007).

Method 2 - Animal in an upright position, attached to plastic buckets' walls $-19 \times 25 \times 23 \mathrm{~cm}$ bucket (Solla et al., 2001).

Method 3 - Shake the animal in a vertical position, with its head up (Solla et al., 2001).

Method 4 - Pressing the head and hind limbs, in this methodology the turtles were captured by hand (Rodrigues et al., 2014). The specimens were sexed according to the tail length - males with the pre-cloacal length greater than females Rueda-Almonacid et al. (2007). The males had their limbs and heads immobilized. On some occasions, a little pressure was applied to the pelvic limbs and head in order to accelerate eversion in males who were calm (they did not try to bite or move their limbs, head and tail; their only action was to retract the neck and limbs when handled). The method was tested at most twice on each specimen, the second trial being carried out only if the first had a negative result, in order to avoid excessive stress. Eversion occurred after a few seconds, which was dependent on the level of animal stress (most stressed individuals everted the penis completely in $9 \mathrm{~s}$, while calmer turtles partially everted the phallus in approximately $30 \mathrm{~s}$ ). All animals retracted the penis after release and had no change in their normal behavior (Rodrigues et al., 2014). 
Method 5 (new method) - Stimulus to the head, displacing the head from the resting position, keeping it in this condition for up to five minutes.

The five methods were tested in all males whenever it was possible, as inserted in results below, 60 minutes after phallus inversion, for this purpose, they were kept in ice until adequate muscle relaxation for proper handling was obtained.

\subsection{Statistical analysis}

The derivative of sexuality was calculated through the hypothesis $\mathrm{df}=\mathrm{dm}$, and the ratio $q=\hat{\partial}$, being: $\mathrm{d}=$ derivative, $\mathrm{f}=$ female, $\mathrm{m}=$ male.

We checked whether morphometry was able to establish the sex through the Wilcoxon-Mann-Whitney test with 95\% confidence and n-1 degrees of freedom (DF).

The success rate between phallus eversion methods and frequency polygon sexing has been established (Zar, 2010).

The methods achieving a success rate higher than $80 \%$ were compared with regard to the time required for phallus eversion stimulation. Differences were submitted to the Student $t$ test with 95\% confidence and n-1 DF.

\subsection{Authorisation and licence}

SISBIO 61118-1 authorisation for collection and transport.
Ethics Committee on Animal Use: Process 23107.018093/2018-73 (Protocol 30/2018 - UFAC Universidade Federal do Acre - Federal University of Acre).

\section{Results}

Regarding the sex ratio between males and females, considering that, in the sample, we obtained 38\% males to $62 \%$ females, the results can be expressed by deriving $3 \mathrm{dm}=5 \mathrm{df}$ meaning that, for this specific sample, we have a population ratio of 3 males for every 5 females $(\mathrm{df}=31$; $\mathrm{dm}=19: \mathrm{df}=2 \mathrm{dm}: \mathrm{df} / \mathrm{dm}=2)$, ie sexual maturity of $1 / 2 \precsim$ for each $\circ$.

By submitting the biometric values measured to the Wilcoxon-Mann-Whitney test (as shown in Table 1) we could establish that there were significant differences between males and females in plastron width and body mass only; however, it was not possible to establish a phenotypic pattern that would back up the assertion for sexual determination.

When comparing the carapace size, we did not find any significant differences (as shown in Table 1) between males and females. When comparing tails, between male and female specimens, in their respective phenotypes, we see that they are similar and their plastrons have no concavity (see Figure 1).

Table 1. Wilcoxon-Mann-Whitney test. (LCL) Linear carapace length, (CW) Carapace width, (PL) Plastron length, (PW) Plastron width in centimeters (95\% confidence level for n-1 D.F. (degrees of freedom), ${ }^{\text {ns }}$ - not significant).

\begin{tabular}{cccccc}
\hline & LCL & CW & PL & PW & Body Mass \\
\hline Statistics & 73 & 91 & 84 & 30.5 & 81 \\
P-value & $0.81^{\mathrm{ns}}$ & $0.25^{\mathrm{ns}}$ & $0.17^{\mathrm{ns}}$ & 0.00 & 0.00 \\
Male & $23.04 \pm 3.59$ & $18.43 \pm 2.49$ & $18.15 \pm 2.53$ & $13.15 \pm 1.76$ & $1.15 \pm 0.38$ \\
Female & $25.35 \pm 5.34$ & $20.45 \pm 4.39$ & $20.34 \pm 4.91$ & $15.91 \pm 7.32$ & $1.60 \pm 0.80$ \\
\hline
\end{tabular}

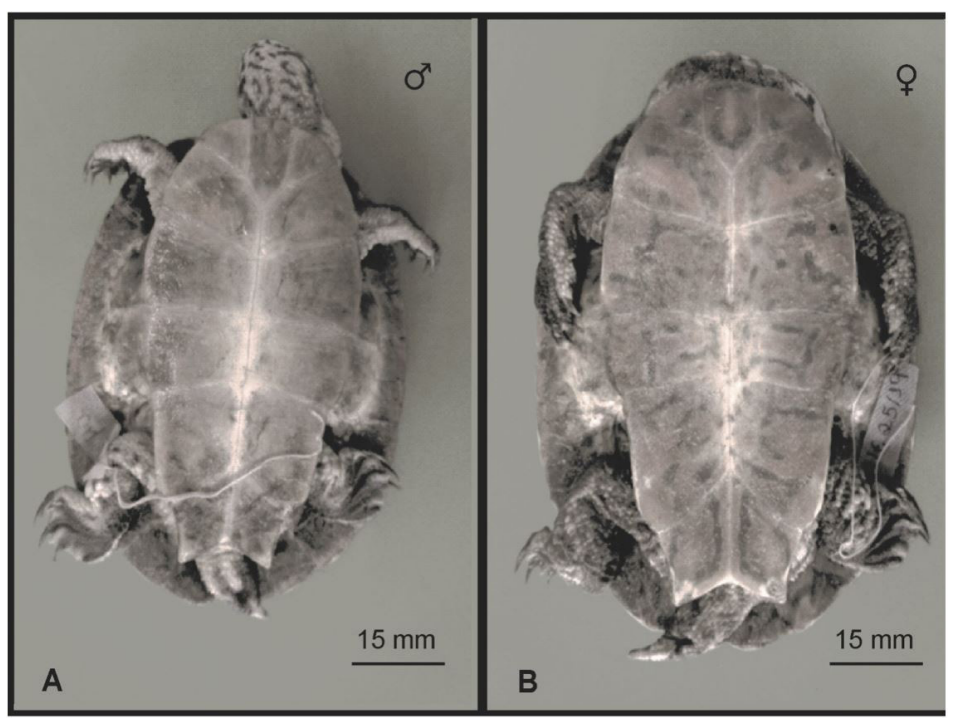

Figure 1. Phrynops geoffroanus in (A) ventral view of the male; (B) Ventral view of the female; Greater tail prominence in female (B) and absence of plastron concavity in both sexes. 
Method 1 could not be performed because the cloaca of the focal species' individuals does not have sufficient opening to perform the procedure.

Looking at the results of methods 2 and 3 , we see that the LCL (linear carapace length) places limits on sexing, as phallus eversion results only occur with measurements $\geq 17 \mathrm{~cm}$. In the present study 32 individuals measured between 17.5 and $24.3 \mathrm{~cm}$ with phallus eversion occurring, by method 2 , in only three out of 15 males within this range of plastron width. For methods 4 and 5 the results were satisfactory for individuals within the LCL range from 10 to $34 \mathrm{~cm}$.

Calculating the success rate, we found: for method 2: 20\%; method 3: 78\%; method 4: $91 \%$ and method 5: $100 \%$ (see Figure 2).

Only 14 out of the 19 males submitted to methods 4 and 5 to verify the time required for stimulation and the phallus eversion success rate responded again to the stimulus performing phallus eversion. The other five did not respond to stimuli, with method 5 requiring less containment and eversion occurred between 0'1" and 4'33", while in method 4 eversion occurred between 3'17" and 6'33" (see Figure 3 and 4).

Time differences between methods 4 and 5 were subjected to Student's t-test and showed a statistically significant difference, meaning that, statistically, method

\section{Succes rate per phallus evertion method}

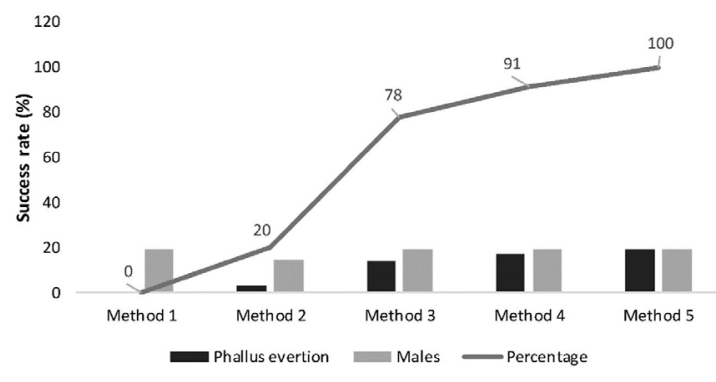

Figure 2. Frequency polygon between success rate and phallus eversion methods in Phrynops geoffroanus.

\section{Stimulation for phallus eversion}

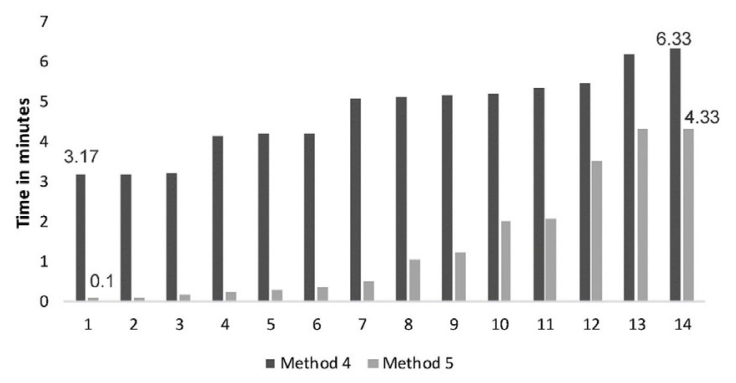

Figure 3. Timing of stimulus time required for phallus eversion in Phrynops geoffroanus, for methods 4 and 5.
5 also presented significant values of shorter time for restraint and sexing (Table 2).

\section{Discussion}

Mendonça (2012), evaluating the sex ratio of Phrynops geoffroanus in Pirapitinga, an ecological station in the Brazilian state of Minas Gerais, found a sex ratio without significant difference, there being 9 males and 11 females. In addition, 3 individuals had undefined sex, due to their immature size.

Sex distinction in P. geoffroanus can also be done by assessing tail length and cloacal width, with the male having the most distal cloaca. Working with Chelydra serpentina, no relationship was found between tail size considering the post and pre cloacal plaque portions (Mosimann and Bider, 1960). In this case, males have longer tails than females. Silveira et al. (2012) when studying Trachemys dorbigni, established that the curvilinear length of the carapace and the cloacal orifice are sufficient for sexing, for this species. However, Bujes (2011) was not able to distinguish the sex of young individuals using this methodology.

Sexual dimorphism through body size and mass are given as phenotypic aspects that allow sexing, with males being smaller in body size and mass, adult females reaching up to $350 \mathrm{~mm}$ in length and $2.5 \mathrm{~kg}$ of body mass (Bujes, 2011; Rueda-Almonacid et al., 2007). In the case of Traquemys scripta, males reach maturity at about $100 \mathrm{~mm}$, in length, while females reach $200 \mathrm{~mm}$ (Gibbons and Lovich, 1990). Thus, smaller sizes did not allow the separation and, therefore, the establishment of the sexuality ratio.

The use of morphometrics and phenotyping as sexing tools are subject to significant errors (Mosimann and Bider, 1960; Solla et al., 1998) which may jeopardise compromise the research and understanding of population dynamics. Thus, the exposure of the phallus is the guarantee of concrete sexing. In our study, even in $10-\mathrm{cm}$ individuals, phallus eversion was possible. Smaller individuals were not found and the mean linear carapace length was $24.0 \pm$ $4.0 \mathrm{~cm}$.

Out of the five intended methods for phallus eversion, method 1 (introduction of a finger into the cloaca - RuedaAlmonacid et al., 2007) was not sampled due to the lack of opening of the cloaca.

As for method 2 - Animal in an upright position, attached to the walls of plastic buckets (Solla et al., 2001), there is a need for several buckets according to the size of each individual, so that the animal gets trapped, because the

Table 2. Student $t$ test for evaluation of the stimulus time required for phallus eversion (95\% confidence level for n-1 D.F.).

\begin{tabular}{cc}
\hline T statistics & $\mathbf{1 4 . 4 0}$ \\
\hline P-value & $2.26 \mathrm{E} 09$ \\
Method 4 & 4.71 \\
Method 5 & 1.44 \\
\hline
\end{tabular}


width of the plastron/carapace must prevent movement in such a way that this entrapment promotes phallus eversion. The authors proposing verticalizing the animal in buckets reported that the eversion results were randomised while transporting the animals, without establishing any morphological and morphometric parameters.

For method 3 - Swing the animal in a vertical position with its head up (Solla et al., 2001), we see that, among the 50 individuals, of which 19 were male, five did not reverse the phallus, probably because they measured less than $16 \mathrm{~cm}$ LCL.

When evaluating method 4 - Pressing the head and hind limbs (Rodrigues et al., 2014), we obtained a 91\% success rate, while in method 5 - Stimulating the head, displacing it from rest position in this condition for up to five minutes, we had a $100 \%$ success rate. It was not possible to know how long Rodrigues et al. (2014) took to achieve successful phallus eversion. In the method proposed in the present work eversion occurred between 0.1 and 4.33 minutes.

The reasons why we were not successful in eversing the phallus with 5 adult individuals may have been based on individual physiological factors of each specimen since they were all subjected to the same method. Rodrigues et al.
(2014) also observed failure of phallus eversion in five individuals out of 33 analysed. The same authors attributed the calm behavior of these specimens. In addition, they ruled out the possibility of these specimens being female, since these, when stimulated, can observe cloacal eversion. However, these effects were also not observed. Studies conducted on $P$. geoffroanus are still in their early stages and require further morphophysiological analysis Cabral et al. (2011).

Phallus eversion occurred partially and completely in young mature individuals (see Figure 4). Due to the body's having been in ice prior to handling, it was not necessary to shake the animal, a condition necessary in the study conducted by Rodrigues et al. (2014).

The method 5, proposed in this study, offers advantageous conditions for the management of $P$. geoffroanus turtles because of its efficiency, and can be performed by a single professional, causing relaxation of the animal with the use of ice in a styrofoam box, thus reducing the time in which the animal is left to struggle, thereby alleviating or preventing sequelae, allowing the animal to be healthily released or the clinical management to cease.

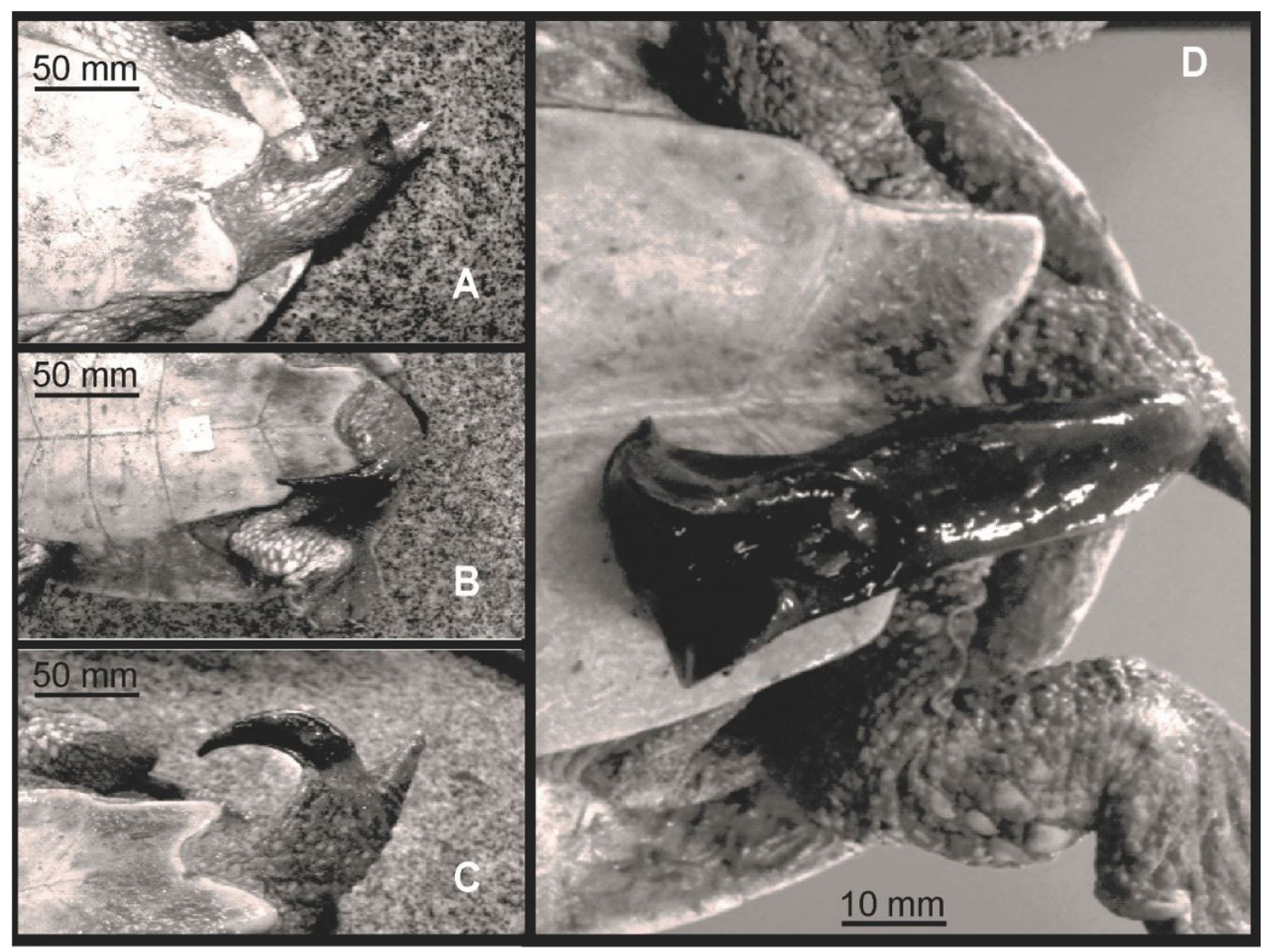

Figure 4. Phrynops geoffroanus' phallus eversion in three stages: (A) primary with only the apical portion; (B) partial engorgement; (C) total engorgement; (D) engorgement with apical exposure. 


\section{References}

ANDRADE, P., CANTO, S. and MONJELÓ, L., 2008. Criação e manejo de quelônios no Amazonas. Manaus: FAPEAM, 272 p.

BENÍCIO, R.A. and FONSECA, M.G., 2014. Guia ilustrado de anfíbios e répteis de Picos-Piauí. Piauí: EDUFPI. 126 p.

BUJES, C., 2011. Os Testudines continentais do Rio Grande do Sul, Brasil: taxonomia, história natural e conservação. Iheringia, vol. 100, no. 3, pp. 413-424.

CABRAL, S.R.P., DE SOUZA SANTOS, L.R., FRANCO-BELUSSI, L., ZIERI, R., SARANZ ZAGO, C.E. and DE OLIVEIRA, C., 2011. Anatomy of the male reproductive system of Phrynops geoffroanus (Testudines: chelidae). Acta Scientiarum. Biological Sciences, vol. 33, pp. 487-492.

CONCEIÇ̃̃O, A.M., ALMEIDA, B.M., BRASILEIRO, M.T.R., BARROS, L.E.D., WILTSHIRE, S.A. and SARMENTO, C.A.P., 2009. Hermafroditismo em jabuti piranga (Geochelone carbonaria). Arquivo Brasileiro de Medicina Veterinária e Zootecnia, vol. 61, no. 6, pp. 1478-1481. http://dx.doi.org/10.1590/S010209352009000600036

FERRARA, C.R., BERNARDES, V.C.D., WALDEZ, F., VOGT, R.C., BERNHARD, R., BALESTRA, R.A.M., BATAUS, Y.S.L. and CAMPOS, J.V., 2016. História natural e biologia dos quelônios amazônicos. In: R.A.M. BALESTRA, ed. Manejo conservacionista e monitoramento populacional de quelônios amazônicos. Brasília: IBAMA, pp. 15-28.

FREITAS, M.A. and SILVA, T.F.S., 2007. A herpetofauna das caatingas e áreas de altitudes do Nordeste brasileiro: guia ilustrado. Pelotas: USEB, $384 \mathrm{p}$.

GARBIN, R.C., KARLGUTH, D.T., FERNANDES, D.S. and PINTO, R.R., 2016. Morphological variation in the Brazilian Radiated Swamp Turtle Acanthochelys radiolata (Mikan, 1820) (Testudines: chelidae). Zootaxa, vol. 4105, no. 1, pp. 45-64. http://dx.doi. org/10.11646/zootaxa.4105.1.2. PMid:27394764.

GIBBONS, J. and LOVICH, J., 1990. Sexual dimorphism in turtles with emphasis on the slider turtle (Trachemys scripta). Herpetological Monograph, vol. 4, pp. 1-29. http://dx.doi.org/10.2307/1466966.

MENDONÇA, S.H.S.T., 2012. Inventário de cágados na estação ecológica de Pirapitinga - Minas Gerais. Relatório de atividades. Lagoa Santa: ICMBIO.

MOLINA, F.B., 1998. Comportamento e biologia reprodutiva dos cágados Phrynops geoffroanus, Acanthochelys radiolata e Acanthochelys spixii (Testudines, Chelidae) em cativeiro. Revista de Etologia, no. especial, pp. 25-40.

MOLINA, F.B., 1992. O comportamento reprodutivo de quelônios. Biotemas, vol. 5, no. 2, pp. 61-70.

MOLINA, F.B., MACHADO, F.A. and ZAHER, H., 2012. Taxonomic validity of Mesoclemmys heliostemma (McCord, Joseph-Ouni \& Lamar, 2001) (Testudines, Chelidae) inferred from morphological analysis. Zootaxa, vol. 3575, no. 1, pp. 63-77. http://dx.doi. org/10.11646/zootaxa.3575.1.4.

MOSIMANN, J.E. and BIDER, J.R., 1960. Variation, sexual dimorphism, and maturity in a quebec population of the common snapping turtle, Chelydra serpentina. Canadian Journal of Zoology, vol. 38, no. 1, pp. 19-38. http://dx.doi.org/10.1139/z60-003.

OLIVEIRA, E.L.R., MELO, L.L., SILVA, E.M., LIMA, V.F.S. and ESCODRO, P.B., 2015. Penectomia total em Geochelone carbonaria (Spix, 1824): relato de caso. Enciclopédia Biosfera, vol. 11, no. 22, pp. 2322-2328. http://dx.doi.org/10.18677/Enciclopedia_ Biosfera_2015_203.
PESSOA, C.A., RODRIGUES, M.A., KOZU, F.O., PRAZERES, R.F. and FECCHIO, R.S., 2008. Ooforectomia videoassistida por acesso préfemural em targaruga-de-ouvido-vermelho (Trachemys scripta elegans). Pesquisa Veterinária Brasileira, vol. 28, no. 7, pp. 345349. http://dx.doi.org/10.1590/S0100-736X2008000700005.

RODRIGUES, J.F., SOARES, D. and SILVA, J., 2014. Sexing freshwater turtles: penile eversion in Phrynops tuberosus (Testudines: Chelidae). Acta Herpetologica, vol. 9, pp. 259-263.

RUEDA-ALMONACID, J.V., CARR, J.I., MITTERMEIER, R.A., RODRIGUEZMAHECHA, J.V., MAST, R.B., VOGT, R.C., RHODIN, A.G.J., OSSAVELÁSQUEZ, J., RUEDA, J.N. and MITTERMEIER, C.G., 2007. Las tortugas y los cocodrilianos de los paises andinos del tropico. Bogotá: Conservacion Internacional Colombia, 538 p.

SANTOS, A.L.Q., MAGALHÃES, L.M., LIMA, C.A.P., NASCIMENTO, L.R., MENEZES, L.T., KAMINISHI, A.P.S., ALVES-JÚNIOR, J.R.D. and ÁVILA-JUNIOR, R.H., 2011. Anestesia de tartaruga-daamazônia Podocnemis expansa (Schweigger, 1812)-Testudines, Podocnemididae, com a associação cetamina e propofol. Pubvet, vol. 5, no. 19, pp. 1118-1123. http://dx.doi.org/10.22256/pubvet. v5n19.1120.

SHINE, R., AMIEL, J., MUNN, A.J., STEWART, M., VYSSOTSKI, A.L. and LESKU, J.A., 2015. Is "cooling then freezing" a humane way to kill amphibians and reptiles? Biology Open, vol. 4, no. 7, pp. 760-763. http://dx.doi.org/10.1242/bio.012179. PMid:26015533.

SILVEIRA, M.L., HARTMANN, M.T. and BAGER, A., 2012. Biometria, razão sexual e dimorfismo sexual de Trachemys dorbigni (Duméril \& Bibron 1835) (Testudines, Emydidae) em um açude no município de São Gabriel, Rio Grande do Sul, Brasil. Biotemas, vol. 25, no. 3, pp. 187-193. http://dx.doi.org/10.5007/2175$7925.2012 \mathrm{v} 25 \mathrm{n} 3 \mathrm{p} 187$.

SOLLA, S.R., BISHOP, C.A., VAN DER KRAAK, G. and BROOKS, R.J., 1998. Impact of organochlorine contamination on levels of sex hormones and external morphology of common snapping turtles (Chelydra serpentina serpentina) in Ontario, Canada. Environmental Health Perspectives, vol. 106, no. 5, pp. 253260. http://dx.doi.org/10.1289/ehp.98106253. PMid:9518475.

SOLLA, S., PORTELLI, M., SPIRO, H. and BROOKS, R., 2001. Penis displays of snapping turtles (Chelydra serpentina) in response to handling: defensive or displacement behaviour? Chelonian Conservation and Biology, vol. 4, pp. 187-189.

STEIN, I.V., STEIN, G.G., HLAVAC, N.R.C., LACERDA, L.A. and CARÍSSIMI, A.S., 2015. Perfil hematológico de tigres d'água (Trachemys dorbigni) de uma população do Rio Grande do Sul, Brasil. Revista Veterinária em Foco, vol. 12, no. 2, pp. 119-127.

TERÁN, A.F., 2008. Participação comunitária na preservação de praias para reprodução de quelônios na reserva de desenvolvimento sustentável Mamirauá, Amazonas, Brasil. Uakari, vol. 1, no. 1, pp. 19-30. http://dx.doi.org/10.31420/uakari.v1i1.3.

VOGT, R.C., FAGUNDES, C.K., BATAUS, Y.S.L., BALESTRA, R.A.M., BATISTA, F.R.W., UHLIG, V.M., SILVEIRA, A.L., BARGER, A., BATISTELLA, A.M., SOUZA, F.L., DRUMMOND, G.M., REIS, I.J., BERNHARD, R., MENDONÇA, S.H.S.T. and LUZ, V.L.F., 2019 [viewed 13 March 2021]. Avaliação do risco de extinção de Phrynops geoffroanus (Schweigger, 1812) no Brasil: processo de avaliação do risco de extinção da fauna brasileira [online]. Brasilia: ICMBio. Available from: https://www.icmbio.gov.br/ portal/faunabrasileira/estado-de-conservacao/7418-repteisphrynops-geoffroanus-cagado-de-barbicha

ZAR, J.H., 2010. Biostatistical analysis. Upper Saddle River: Pearson Prentice-Hall, 944 p. 